Revista de Filología Románica

ISSN: 0212-999X

http://dx.doi.org/10.5209/RFRM.63623

\title{
Representacións literarias e fílmicas do Vigo contemporáneo
}

\author{
Alba Diz Villanueva ${ }^{1}$
}

Recibido: 22 de julio de 2018/ Aceptado: 22 de noviembre de 2018.

Resumo. O obxectivo do presente traballo é presentar as metáforas recorrentes nas representacións da cidade de Vigo na literatura e no cine, con especial atención á imaxe totalizadora que está presente en todas elas, a cidade hostil. O estudo analiza as distintas causas de hostilidade urbana que se poden recoñecer nas películas e textos literarios.

Palabras chave: Vigo; metáforas urbanas; cidade hostil; recreacións literarias e fílmicas.

\section{[en] Literary and filmic representations of modern Vigo}

\begin{abstract}
The aim of this paper is to present the recurrent metaphors in the literary and filmic representations of Vigo, paying attention to the main image in all of them, hostile city. This study analyzes the different causes of this urban hostility that can be recognized in films and literary texts.

Keywords: Vigo; urban metaphors; hostil city; literary and filmic representations.
\end{abstract}

Sumario: 1. Introdución. 2. Metáforas urbanas. 3. A cidade hostil. 4. A outra cara de Vigo: trazos positivos. Bibliografía.

Cómo citar: Diz Villanueva, A. (2019). Representacións literarias e fílmicas do Vigo contemporáneo, en Revista de Filología Románica 36, 201-218.

\section{Introdución}

O presente traballo analiza as metáforas máis frecuentes nas representacións literarias e fílmicas da cidade de Vigo, un espazo que, aínda que contaba xa cunha importante presenza nas letras desde antigo, experimentou nas últimas décadas un aumento significativo no que a emprazamento de obras artísticas se refire. Esta presenza non se circunscribe ao ámbito da cultura galega senón que se estende tamén as letras universais, grazas a escritores como Jules Verne e o seu Vinte mil leguas baixo dos mares ou a Stefan Zweig, que deixou constancia nas súas memorias Die Welt von Gestern. Erinnerungen eines Europäers ("O mundo de onte. Memorias dun europeo") da escala que realizou na cidade -a derradeira en territorio europeo- a nave na que ía embarcado camiño dos Estados Unidos. O corpus, sen pretender ser ex-

\footnotetext{
1 Departamento de Estudios Románicos, Franceses, Italianos y Traducción - Universidad Complutense de Madrid albadiz@ucm.es
} 
haustivo, abrangue algúns dos exemplos máis salientables das recreacións artísticas da cidade olívica, desde as derradeiras décadas do pasado século ata os nosos días. ${ }^{2}$

Cidade periférica e portuaria, núcleo urbano importante que concentra poboación dunha ampla zona xeográfica circundante, Vigo presenta unha serie de características que a converten nun escenario atractivo desde o punto de vista literario e, aínda que en menor medida, tamén fílmico. A este respecto sinala Manuel Forcadela no seu escrito "Vigo literario" (Forcadela s.d.):

Esta cidade en rede, tan semellante a moitas cidades americanas e situada no mesmo paralelo que Nova York, sería, por vocación e por historia, a impulsora da modernidade en Galicia e aínda, alén diso, da posmodernidade. Se Compostela é a tradición milenaria, a plasmación en pedra dun xeito de ser que vai desde o románico ao barroco, Vigo sería o caos, lugar de confrontación das diferentes tensións ideolóxicas e sociais, o punto en que se entrecruzan o moderno e o tradicional, o autóctono e o alleo.

Nestas últimas liñas condénsanse as principais dicotomías que vertebran as representacións literarias de Vigo. A definición da cidade como espazo caótico, de confrontacións e tensións, adianta xa cal vai ser o modelo ou a imaxe principal na recreación deste espazo: a cidade hostil. A literatura, como o cine, aproveita o potencial artístico destas peculiaridades do entorno vigués para desenvolver a trama e moitas delas resultan deste xeito, ao seren ficcionalizadas, se cadra máis adversas. Non obstante, hai outras metáforas recorrentes que persisten nas distintas obras contempladas neste traballo, que vou referir antes de centrarme nos focos de hostilidade urbana.

\section{Metáforas urbanas}

Un dos modelos culturais urbanos de amplísima tradición literaria que atopamos nas imaxes artísticas do Vigo contemporáneo é o da cidade-corpo, aquela que equipara a urbe a un organismo humano, identificando determinadas partes da xeografía viguesa con membros ou órganos, segundo sexa a súa forma, a súa función, a súa posición ou os valores que portan, ou ben sometendo a cidade a un proceso de personificación que a presenta como un ser capaz de accións e sentimentos humanos.

En Amor de tango, de María Xosé Queizán, as rúas do Berbés, de trazado irregular, con casas dispostas de xeito non lineal, con xiros e baixadas inesperadas, transmiten unha sensación de movemento e de retorsión que da lugar á comparación deste barrio cun "ventre dorido" (Queizán 2014: 115). Contribúe a esta metáfora o feito de tratarse da principal zona de abastecemento da cidade: se para Zola o "ventre de

\footnotetext{
O corpus literario está formado por Adiós María, de Xohana Torres (1971); Antón e os inocentes, de Xosé Luis Méndez Ferrín (1976); Cemiterio de elefantes e Cidades, de Fran Alonso (1994 e 1997, respectivamente); Panificadora, de Xosé Cid Cabido (1994); Amor de tango e Ten o seu punto a fresca rosa, de María Xosé Queizán (1998 e 2000, respectivamente); O club da calceta, de María Reimóndez (2006); Cardume, de Rexina Vega (2007); Fóra do sagrado, de Anxo Angueira (2007); Os fillos do mar (2012), Os fillos do lume (2017) e, secundariamente, Camiñar o Vigo vello: un paseo pola historia da cidade e Sen piedade (ambos os dous de 2018), de Pedro Feijoo. Pola súa banda, as películas contempladas son Lena (Gonzalo Tapia, 2001), Los lunes al sol (Fernando León de Aranoa, 2002) y Heroína (Gerardo Herrero, 2005).
} 
París" era o mercado de abastos, o ventre de Vigo son para Queizán o porto pesqueiro e as súas inmediacións, o núcleo en torno ao cal xermina, crece e se desenvolve a cidade.

O Vigo nocturno de Fran Alonso identifícase cun corpo de "entrañas depresivas e violentas" (Alonso 2007: 16). Vista desde lonxe, a forma da cidade é descrita de acordo coa metáfora corporal:

A medida que o coche se vai achegando á cidade, Vigo perfílase coma un xigante atragantado e torpe que se deita sobre un val entre montañas e latexa con arritmia, contraéndose e estirándose de forma convulsa. A súa figura abrupta vaise desdebuxando cando o coche avanza pola estrada do aeroporto para ser devorada pola urbe. Vista desde a Avenida do Peinador, a cidade semella un corpo que se desangra. Sempre lle causara esa impresión e non deixaba de lle producir certo horror. Logo de deixar atrás a recta de Candeán, ve como, alá embaixo, as luces das rúas marcan as arterias doridas dun corpo de asfalto e cemento (Alonso 2007: 67).

A mesma imaxe da cidade como un corpo que se desangra reaparece no libro de poemas titulado Cidades. En tanto que organismo, a cidade pode enfermar, sentir dor, convulsionar (Alonso 2013: 35); ten pel e ten corazón: a primeira muda, o segundo cambia de cor (Alonso 2013: 53). Ademais, a cidade é contemplada sempre en relación co seu mar, unha relación que neste caso se presenta como amorosa, resultando ambos personificados: as partes adxacentes ao mar son os beizos cos que a cidade o bica, e este devólvello cos seus propios beizos (Alonso 2013: 15). Nesta mesma obra, prodúcese a metáfora contraria á cidade-corpo: a do corpo-cidade, o organismo concibido como unha urbe, onde os elementos que o conforman aparecen novamente como termos das comparacións máis frecuentes no anterior modelo, agora invertidas: as veas e as arterias son aquí as estradas e vías por onde discorre o tráfico de automóbiles, as lágrimas que xorden ao chorar son o mar "que se revolve / humida mente", os edificios e arrabaldes que se estenden pola superficie urbana conforman a pel...

A novela Panificadora, de Cid Cabido, non está exenta tampouco das imaxes corporais na descrición do espazo urbano. Así, por exemplo, o control da empresa na que traballa o protagonista é tal que a súa sede, o edificio Chup \& Chup, é un ente vivo que estende os seus "brazos maléficos" sobre os habitantes (Cid Cabido 1994: 56), mentres que o seu interior descríbese como "ventre noxento" (Cid Cabido 1994: 70) no que se entra a través dos ascensores, cuxas portas son bocas metálicas que "expresaban mellor ca ningunha outra cousa o mecanicismo voraz do Gran Monstro capitalista que era Chup \& Chup..." (Cid Cabido 1994: 144). Se a empresa e o seu edificio son un ventre, a cidade que vive baixo o seu xugo é o resultado da súa dexección, é unha Cidade-Váter. Seguindo coa metáfora escatolóxica, o portal dun dos seus edificios é unha cloaca e o ascensor, unha fosa séptica, mentres que os seus habitantes non acadan xa a condición de seres humanos, senón que son criaturas híbridas, "homes-rata".

De entre os autores estudados, un dos máis prolíficos en canto á aplicación de termos relacionados coa anatomía humana á xeografía viguesa é Pedro Feijoo. En Os fillos do mar, a rúa de Urzáiz é ben "unha longa gorxa que engulía todo o tráfico humano", ben "a gran vea cava da cidade"; Policarpo Sanz, é "a grande arteria"; e a Alameda e os seus arredores, o corazón (Feijoo 2013). As principais rúas da cidade 
son, segundo esta identificación, os condutos encargados do mantemento do fluxo vital, que no son senón os seus transeúntes.

A humanización da cidade vai un paso máis adiante en Os fillos do lume. Máis aló das comparacións concretas que poden continuar con esa identificación entre corpo humano e corpo urbano, nesta novela a cidade é representada, en conxunto, coma unha muller capaz de sentir e provocar sentimentos, incluso de natureza amorosa. Así, a coprotagonista da serie ${ }^{3}$ Mariña, rivaliza coa urbe olívica polo amor do seu home, Simón:

Quéreme, seino, pero non esquezo que tamén está namorado dela. Cando non pode durmir, ás veces érguese e, sen facer ruído, desaparece. Baixa á rúa, e corre na súa procura. [...] Sae, e camiña en silencio rúa abaixo, as mans afundidas nos petos do pantalón. Pérdese na escuridade sen dicir nada, como sen rumbo, ata que por fin se detén, fronte a un dos vellos edificios. Ante unha casa antiga. Ante un portal sen placas de ningún tipo. Ante un recuncho esquecido. Vinos moitas veces desde a distancia, falándose sen dicírense nada. Coma se ambos se acariñasen en silencio e, despois, el regresa á casa. Simón está namorado da cidade, e nela busca acubillo e consello cando ninguén máis llos pode dar. El cre que non o sei, pero eu coñezo o seu segredo (Feijoo 2017).

A forma da cidade da lugar, ademais de ás xa mencionadas metáforas corporais, a comparacións e imaxes de distinta índole e carga connotativa. Unha delas, que aparece a miúdo nos textos literarios estudados, é a do labirinto e outras análogas, que subliñan o empinado e sinuoso das rúas viguesas, proclives á perda e á desorientación. En Cardume, a cidade pontevedresa defínese como "Pequeno dédalo de rúas" (Vega 2007: 182), que, coa súa expansión e crecente dimensión é xa, segundo Anxo Angueira en Fóra do sagrado, un "labirinto [...] deforme / informe inmenso infotografábel” (Angueira 2006: 30-31). Pedro Feijoo recorre a esta imaxe nas súas últimas obras publicadas, tanto na novela Sen piedade, para referirse ao barrio de Bouzas - "un labirinto de pedra con nomes de santos por todas as partes e rúas pechadas coma puños" (Feijoo 2018b)-, como en Camiñar o Vigo vello. Un paseo pola historia da cidade, unha obra de non ficción, a medio camiño entre a guía turística e un manual histórico, na que alude á parte antiga da urbe coma un "labirinto de pedra e sombra, de luz e auga" (Feijoo 2018a: 12). Pola súa banda, sen dúbida inspirado nestas mesmas características, Fran Alonso opta polas metáforas de cidade-anguía e cidade-serpe, engadindo o carácter animado, a animalización da urbe.

\section{A cidade hostil}

Como afirma Matas Pons (2010: 20), "el discurso de la ciudad es el de una densa configuración social hecha de acontecimientos, intereses, personas y textos en constante disputa". A cidade, como espazo vital, presenta elementos que dificultan a vida dos seus habitantes, tanto na súa propia configuración como nas actividades

Mariña Dafonte e Simón Varela son os protagonistas de Os fillos do mar e de Os fillos do lume. En ambas as dúas novelas asumen a función de investigadores dun ou de varios crimes, relacionados ben coa súa familia (coma no caso dos Dafonte no primeiro volume), ben con algún coñecido (no caso do segundo). 
políticas, sociais ou económicas que teñen lugar no seu seo. Os autores que toman a cidade como espazo predilecto das súas obras explotan a miúdo esta face hostil, conscientes da súa produtividade, en tanto que xera tensións que derivan en conflitos de todo tipo. Así, son frecuentes as reescrituras nas que a urbe é escenario do crime, de torturas, de comercio sexual, de mendicidade, de violacións ou de tráfico e consumo de drogas (Popeanga Chelaru 2015: 33).

Cando falo de hostilidade, un concepto amplo, refírome tanto á hostilidade directa, externa, relacionada coa propia configuración urbanística, como a manifestacións indirectas, nas que a adversidade urbana se reflicte de forma latente. A hostilidade presenta tamén diferentes graos de intensidade, desde a violencia (física ou psicolóxica, criminal, institucional...), ata certos aspectos que, aínda que non fan da cidade un entorno intrinsecamente hostil, si contribúen a unha percepción negativa da mesma. Estes elementos de hostilidade urbana, como poden ser infraestruturas deficientes, contaminación ou actividades económicas agresivas - que provocan molestias, tráfico, ruídos...-, poden, segundo sexa o seu grao de incidencia ou a súa combinación con outros factores, facer que a cidade torne hostil, ou ben, naqueloutros casos nos que a complexidade da cidade fai más difícil cualificala nestes termos, poden permanecer como elementos negativos que toman parte dunha entidade máis ampla e rica (Prada-Trigo 2015: 52) .

Se ben o xénero criminal é aquel que en principio parece máis proclive a unha representación da cidade como entorno hostil, non é o único que se fai eco do rostro máis violento da mesma. Noutras moitas obras non pertencentes ao xénero negro vemos un Vigo escenario de agresións, de torturas, de violacións (como a que sofre Narda en Antón e os inocentes) e, incluso, de asasinatos. ${ }^{4}$ Por exemplo, en Ten o seu punto a fresca rosa, de María Xosé Queizán, algúns dos lugares máis emblemáticos ao par que fermosos da cidade tornan o seu signo ao se converteren en escenarios dun crime. A personaxe nexo das distintas historias que conforman a novela, a moza María, morre envelenada no monte de O Castro, un espazo en principio tranquilo, onde se atopa a súa propia vivenda e onde transcorre tamén o seu tempo de lecer. A praia de Samil, pola súa parte, outro belido enclave de recreo para moitos vigueses, acolle $\mathrm{o}$ asasinato dunha prostituta.

A representación quizais máis negativa de Vigo vén da man de Fran Alonso e o seu Cemiterio de elefantes. A maioría dos relatos presenta unha cidade nocturna que ampara todo tipo de actos violentos e que oprime, que asfixia os seus habitantes. O desacougo, a desesperación, a soidade e o medo son algúns dos sentimentos dominantes nesa fauna nocturna, constituída por vagabundos, insomnes, noctámbulos, borrachos, toxicómanos ou traballadores que resisten a súa quenda a base de café, alcohol ou cocaína. Os habitantes da noite, "cemiterio de elefantes", acceden a una cara distinta, deprimente, da cidade, descoñecida para os habitantes do día: rúas desertas, sucias, cheirentas e desapracibles, clínicas de urxencias, farmacias de garda, discotecas ou instalacións portuarias, que son escenario de suicidios, sobredoses, tortura, violacións e homocidios. O carácter sedutor e fascinante que unha

Cabe sinalar, non obstante, que os asasinatos non sempre son presentados como un factor hostil. En $O$ club da calceta de María Reimóndez, os crimes, que toman aparencia de accidentes, supoñen unha verdadeira liberación, exenta de calquera condena ou remordemento, para as protagonistas. Ben ao contrario, a hostilidade procede precisamente daquilo que motiva os homicidios: a opresión, o maltrato, a denigración, etc. que sofren las mulleres por parte daqueles homes aos que, como parece suxerir a novela, finalmente asasinan. 
das personaxes, Rosi, procedente de Mougás, percibe nese enigma que é para ela a noite viguesa, e que convive con esoutro sentimento de inquietude e inseguridade nese medio tan distinto do rural, desaparece en virtude da hostilidade, que se impón cando, nun dos seus paseos nocturnos, é violada. A cidade, como a noite, é definitivamente "atroz, criminal, [...] animal, salvaxe" (Alonso 2007: 9-10).

Dentro desta imaxe da cidade como entorno hostil, que nos relatos de Fran Alonso é total, pódense distinguir determinadas causas ou fontes, que se deixan ver, en maior ou menor medida, en case todas as obras analizadas. Dous dos principais focos da delincuencia na cidade, estreitamente relacionados, son, sen dúbida, o narcotráfico e a drogadicción, que, ademais de aumentar a conflitividade nas rúas con roubos, atracos ou liortas, se cobran múltiples vidas, sexa directa e violentamente a través de axustes de contas entre traficantes, sexa a consecuencia de sobredoses, enfermidades contraídas polo intercambio de xiringas entre toxicómanos (principalmente VIH), etc. As películas Lena e Heroína transpórtannos a este mundo. A primeira amosa parcialmente as actividades dunha organización criminal que opera en Vigo. Os escenarios principais tanto das actividades da banda como da vida familiar e laboral da protagonista son as zonas de Bouzas, con rúas empinadas, tortuosas, onde abundan os puticlubes que serven de sede aos criminais, e as do porto, coas súas naves industriais e almacéns, espazos que contrastan con aqueloutras zonas, na praia de Patos e arredores, que frecuentan os seus amigos. A cidade, que xa desde o comezo aparece como un entorno hostil do que Lena quere fuxir polo estigma que lle supón pertencer a un estrato social baixo, habitar nun barrio tradicionalmente pesqueiro e, por enriba de todo, ter unha familia non precisamente modélica, négalle calquera oportunidade de progreso e confínaa neses espazos dos que quería escapar. Así, acaba por entrar en contacto de forma directa co narcotráfico e coa violencia que trae aparellada (agresións brutais, extorsións e ameazas, crimes, etc.).

O segundo dos filmes, Heroína, ambientado na década dos 80, nos anos da "movida", amosa as distintas faces do drama que supuxo o narcotráfico na sociedade galega. As rúas de Vigo, especialmente as prazas e as empinadas canellas do Casco Vello, aparecen devastadas pola droga: os toxicómanos inxéctanse a súa dose en calquera parte, abundan os locais onde conseguir heroína e demais substancias, prodúcense atracos nas tendas e bancos co fin de financiar o consumo, as familias loitan inutilmente por desintoxicar os seus fillos e maniféstanse para que se faga xustiza e se condene os narcotraficantes, que se pasean impunemente nos seus coches de luxo, mentres os adictos que non morreron cumpren condena no cárcere. Na guerra que emprenden contra o tráfico de drogas a protagonista - trasunto de Carmen Avendaño- e as súas compañeiras han de loitar contra institucións corruptas, presións, ameazas e incluso intentos de homicidio antes de acadar os seus obxectivos, como a creación da asociación Érguete ou importantes condenas para os narcos.

O comercio sexual é outro foco de hostilidade, que se concentra fundamentalmente en dúas zonas da cidade: a Ferrería, onde se atopan os principais prostíbulos (algúns tan afamados como o bar Abanico, máis coñecido como a casa da Collona, unha verdadeira institución do barrio vermello vigués), e a zona de Beiramar-Berbés, onde as prostitutas expoñen os seus corpos á vista dos seus potenciais clientes, polo xeral condutores. María Xosé Queizán, en Ten o seu punto a fresca rosa, recrea a atmosfera opresiva e abafante dos clubs de alterne, co seu cheiro nauseabundo, mestura de perfume barato, cosméticos, alcohol e cerrazón. Neste mundo de servidume sexual, as mulleres, ademais de ser un branco fácil para psicópatas asasinos (como 
é o caso da vítima de Samil), están expostas á enfermidade, que se reflicte nos seus rostros avellentados e nos seus corpos escuálidos (Queizán 2000: 206). Amor de tango presenta a Ferrería nos seguintes termos: "o barrio máis miserento e sórdido da cidade cos tugurios de puterío e casoupas noxentas" (Queizán 2014: 64). Esta descrición compleméntase coa que ofrece Méndez Ferrín destas mesmas rúas, síntoma da degradación humana:

[...] as cores dos caleixóns proibidos da Ferrería, derradeira degradación mesturada con mexos, cecáis gómito, polas escuras pedras: vellas malditas, deformadas, con perna esquerda fofa [...], labres ostentosamente emborrachados de vermello, ollos tumefactos, saídos das cuncas; nenos brancos, suxos, esqueléticos, rapados ou con trenciñas murchas, que se chaman Chelito, Marisa, Manolito, Jose (non José), Joseantonio ou [...] Juan Carlos; nenos que arrevoan nas mañáns de sol, coma unha bandada de pombas suxas, derredor do Forte de San Sebastián. Nenos delgados, da putería, futuros hóspedes do reformatorio, da lexión, da cadea, eles; das Arrepentidas, das casas de putas outra volta, da cadea ou do «Campo», elas [...]. Cánta turba, entoldada noite, violencia estéril, frustración, círculos delirantes, mar de anis, esplotación, miseria absurda, antre Abeleira Menéndez, o Placer e a Ferrería, coa famosa pianola da Señora Collona ao fondo [...] (Méndez Ferrín 1992: 155).

Tamén María Reimóndez, en $O$ club da calceta, proxecta esta realidade a través dunha das mulleres protagonistas, obrigada a prostituírse pola súa propia nai, que rexenta un puticlub no devandito barrio vermello. Aos problemas xa sinalados por Queizán súmase o da adicción ás drogas, ás que moitas prostitutas recorren para intentar soportar o sufrimento, e o da condena social, que padece quen procede desta zona da cidade, marcada, estigmatizada, e que conduce á reclusión: “[...] non saio case da rúa. Vou ata o supermercado, onde todo o mundo sabe que es puta pola rúa de onde vés [...]. Comprar parece ser o único que proporciona unha escusa para moverse pola cidade. Dentro de pouco seguro que nos fan a teletenda para putas para que non teñamos que saír por aí adiante" (Reimóndez 2006: 185).

Doutra banda, a historia da cidade, o seu crecemento e a súa expansión, tanto económicos como demográficos e, sobre todo, xeográficos, son aspectos que contribúen a xerar a visión negativa da urbe. Boa parte das obras literarias analizadas aluden á insuficiente planificación urbana, ao escaso ou nulo respecto ao patrimonio histórico, ao caótico e acelerado desenvolvemento urbano desde comezos do século $\mathrm{XX}$ - extramuros da antiga cidade fortificada, cara a municipios próximos aos que se foi anexionando (Pereiro Alonso 1981: 55) ou cara ao mar-, en virtude da cada vez máis importante industria pesqueira.

En Cardume, Rexina Vega retrocede a 1917 para amosar un Vigo en pleno crecemento, un Vigo moderno cos seus tranvías recentemente estreados e a súa incipiente burguesía, con roupas e vivendas a medida, que contrastan con aqueles barrios máis humildes e coas súas xentes, ás que o desenvolvemento volve as costas:

Unha urbe moderna de toldos a riscas brancas e vermellas que ensina con orgullo as cicatrices novas do tranvía. Pasan homes con canotiers ou puchas, pasan mulleres con chapeu de plumas ou panos de la. Os carros de bois chían ateigados de pedra para un urbanismo de volutas florais nas balconadas e grandes fiestras 
envoltas en lazos: tortas de granito. Esta é unha cidade colonial en construción rápida. Vigo Nova York, Vigo British abre unha avenida grande e acoutada para os novos ricos, e deixa que a cerna indíxena se precipite dende o alto cara á beiramar nun fervedoiro de edificios e casoupas, altas e baixas, novas e vellas, fermosas e sinistras, comendo o aire nun barullo feo (Vega 2007: 56-57).

A novela presenta un Vigo fronteirizo, a medio camiño entre a modernidade urbana e o mundo rural, entre cidade de provincias e urbe cosmopolita; é, a un tempo, en palabras da autora, "Vigo British" ou "Vigo Gran Mazá" (Vega 2007: 58), dunha banda, e, doutra, "cidade- aldea" (Vega 2007: 68), un espazo onde, a carón de novos edificios que, desde a súa altura, desafían a antiga escala da cidade, atópase unha horta de nabizas. Vigo é, en definitiva, un híbrido, sintetizado no sintagma "aldea-Nova York" (Vega 2007: 62). Como aldea aparece reflectida tamén en Panificadora, imaxe que convive, non obstante, con aqueloutra de entorno avasalador: "Despois de todo, esta cidade non é tan grande [...]. En realidade non é máis ca unha simple aldea" (Cid Cabido 1994: 35).

Un escenario onde se materializa esta realidade é o porto, onde chegan barcos e xentes de todas as partes do mundo e que acolle aínda, malia a súa rápida modernización, a pesca e os transportes de mercancía tradicionais. De acordo coa novela de Rexina Vega, tras os proxectos de reforma do porto hai unha vontade de esquecer a marchas forzadas a súa orixe (pesqueira) e construír "unha illa de novo granito [...], nunha reprodución rápida do bo estilo internacional" (Vega 2007: 74-75). O porto é precisamente un dos lugares da xeografía urbana que máis afectado resulta nese proceso de expansión, cos sucesivos ensanches de que é obxecto, que non fan senón gañar cada vez máis terreo ao mar, como denuncian moitos dos autores tratados. Un verso de Fóra do sagrado de Anxo Angueira, paráfrase parcial dun verso de Manuel Antonio, ${ }^{5}$ condensa á perfección este fenómeno: "Bouzas está tan lonxe que está chegando a Cangas" (Angueira 2007: 43).

María Xosé Queizán é unha das voces máis críticas con desenvolvemento urbanístico, que cualifica de "desfeita” (Queizán 2000: 260), e cos intereses económicos que nel interveñen. Denuncia a especulación inmobiliaria durante o franquismo, cuxa época dourada, a década dos 50 (Pereiro Alonso 1981: 138), trouxo consigo un crecemento apurado e desordenado que responde unicamente á cobiza e que se salda coa demolición de edificios de gran valor arquitectónico e histórico, para construír no seu lugar "moles deformes" (Queizán 2000: 261) carentes de calquera sentido estético e coherencia co entorno, ${ }^{6} \mathrm{O}$ antigo hotel Continental é un dos moitos demolidos "pola piqueta da ambición e da ignorancia durante os anos da ditadura" (Queizán 2014: 77).

Eses intereses económicos, aínda que en menor medida, xa guiaran a planificación urbana anterior, que deu prioridade ao desenvolvemento industrial fronte ao

Trátase dun verso do poema "Lecer", pertencente ao celebérrimo libro de poemas De catro a catro.

Segundo Fran Alonso, en Vigo "tristemente a especulación triunfou por riba da habitabilidade, das persoas, do contorno, da vida" (2004: 20). Como apunta Pereiro Alonso (1981), en Vigo dominan os espazos destinados á edificación e aos intereses económicos, en detrimento do benestar dos seus habitantes. A cidade está "constituida por una ininterrumpida serie de calles corredor que señalan la avaricia de una sociedad [...], calles que incitan al movimiento [...], calles pensadas y realizadas con el principal fin de hacer solares con que traficar, y para contener más y más productos-vivienda, como si la ciudad sólo fuera eso: casas y calles para llegar a ellas" (Pereiro Alonso 1981: 182). 
recreo ou á estética da cidade. Como resultado, as praias do centro da cidade (nas zonas de Bouzas, Coia, Berbés, Areal-Guixar...) foron sacrificadas para albergar no seu lugar os peiraos comerciais, pesqueiros, transatlántico e deportivos, dando lugar a unha paisaxe radicalmente distinta onde os elementos construídos substituíron case por completo aos naturais: barcos, guindastres e demais maquinaria, almacéns, fábricas e empresas.

As praias conservadas foron as máis afastadas do casco urbano, aínda que tampouco todas elas foron necesariamente respectadas. Así, o areal de Samil foi urbanizado na década dos setenta, malia a la oposición de moitos vigueses, ${ }^{7}$ de forma tal que a extensión das súas dunas viuse reducida en gran medida por mor da construción dun un longo paseo, aparcadoiros, cafetarías, etc. En Os fillos do mar, Simón Varela, arquitecto de profesión, subliña o desacertado desta transformación, ao ironizar sobre a incompatibilidade de ter estilo e ser un cliente habitual da cafetaría Jonathan, situada no devandito paseo desde a súa inauguración en 1976 ata 2015, cando abriu no seu lugar un novo local, o Marina Cíes. Preto de Samil, en na antiga aldea pesqueira de Canido, pódese observar un fenómeno similar: mudou o seu carácter e face tradicionais - dos que non quedan máis que algunhas mostras como as gamelas do porto- para converterse nunha zona residencial de luxo, superpoboada, con grandes urbanizacións de chalés e dúplex, que soterraron o pasado do lugar baixo capas de pedra e cimento que se venden a prezos desorbitados.

Tamén o barrio de Coia, unha desas zonas sacrificadas en virtude do (suposto) progreso, é obxecto de proxectos inmobiliarios cuestionables, como os bloques obreiros, homoxéneas caixas de formigón de influencia soviética construídas na década dos setenta para albergar os traballadores de Citroën e doutras fábricas viguesas, procedentes moitos deles do rural galego. Similares a estes cubos son as "colmeas" (empregando o termo de Queizán 2000: 11) das "Casas Acollidas do Axuntamento", onde vive por un tempo a familia de Maxa en Adiós María de Xohana Torres, onde as paredes, finas coma o papel, deixan oír todo tipo de ruídos dos veciños, privando así de toda intimidade os seus habitantes. A isto habería que engadir outras deficiencias estruturais como a escaseza de espazo, a pésima calidade das infraestruturas ou a falta de seguridade.

Estes problemas, que acompañaron ao desenvolvemento de Vigo ao longo da súa historia, especialmente durante o século XX, perduran, segundo o narrado en $O s \mathrm{fi}$ llos do mar, na cidade actual, asolagada por obras constantes que, lonxe de mellorar o aspecto das rúas e demais espazos públicos, convértena nun entorno máis hostil e ruidoso para os transeúntes. Igualmente, a proliferación das cadeas e multinacionais en detrimento do comercio tradicional é outra das consecuencias da especulación sobre o tecido urbano: os McDonald's, os Burger King ou as tendas de Inditex dominan as vías viguesas, homoxeneizándoas e eclipsando o legado arquitectónico que conseguiu sobrevivir ás demolicións indiscriminadas. Nestes tipos de agresión ao patrimonio insiste Feijoo no seu Camiñar o Vigo vello, onde, ademais de listar os edificios e elementos urbanos (murallas, fortes, etc.) destruídos ao longo da historia da cidade, subliña o esquecemento, falta de atención ou indiferenza por parte dos vigueses e das autoridades competentes en materia urbanística respecto tanto do que foi e xa non é como do que aínda queda.

Destaca, como sinala Pereiro Alonso (1981: 155), a forte oposición da Subdelegación en Vigo do Colexio de Arquitectos, polo impacto sobre o entorno natural. 
En Panificadora, de Cid Cabido, onde a cidade de Vigo non se menciona de forma explícita pero si se recoñece por outro tipo de referencias (entre elas, o edificio que da título á novela), o espazo urbano caracterízase tamén por unha configuración caótica e desenfreada á que ninguén parece querer pór límite:

Alá, contra un fondo de piñeiros e algúns eucaliptos, a autovía bordea o encoro ata chegar ó cruce onde conecta coa longa estrada que discorre durante máis de once quilómetros entre casas e almacéns e talleres e desemboca no val polo que o Desastre Urbano medra e se espalla fóra de control sen que ninguén pareza disposto a impedilo (Cid Cabido 1994: 56).

A mesma idea esbozan Anxo Angueira en Fóra do sagrado, con ese "Vigo / derramándose sen formato / por corredoiras corredouras tornecelos/ nadas na sombra inescusables" (Angueira 2007: 30), ou María Reimóndez, que alude á transformación da cidade, á desaparición das antigas casas baixas a favor de altos edificios e "espantallos de bloques" (Reimóndez 2006: 159), que restan visibilidade ás vellas e escasas construcións que sobreviviron, como algunhas igrexas.

O ruído, a sucidade, o tráfico, a contaminación atmosférica e do medio mariño, a escaseza de espazos verdes... son outros factores que acrecentan a concepción da urbe como entorno caótico e adverso para a vida dos seus habitantes. Así é plasmada en Cidades, de Fran Alonso, e así é percibida polos protagonistas de Panificadora e, sobre todo, de Adiós María, de Xohana Torres. Para Maxa, a cidade portuaria en expansión, inspirada en Vigo (Branco 2006: 184), contrasta, por todos estes trazos, coa tranquilidade do suburbio no que vive, Cantador de Enriba:

Este run run da vila,

coches

xentes

ruídos

bucinas, tracatrá, pun, pi, ipero que disparate é unha cidade tan chea, que mareo!

(Torres 2000: 12)

Relacionado coa configuración urbanística, en parte consecuencia dela, está un dos elementos máis destacados na imaxe hostil da cidade: a desigualdade socioeconómica, que se plasma, no curso evolutivo de Vigo, nunha estratificación espacial, con zonas altas, onde habita a poboación acomodada (Alameda, Policarpo Sanz, Colón, Gran Vía ou O Castro), e zonas baixas, onde se concentra a clase obreira (barrios de Teis, Coia, Bouzas, Lavadores, Berbés...). As condicións de vida nestes barrios, na súa meirande parte destinados á vivenda dos traballadores da industria arredor da pesca, son máis duras, tanto pola pobreza en ocasións extrema, como pola conflitividade.

No Vigo das primeiras décadas do século XX, que vemos tanto en Cardume como en Amor de tango, esta distancia socioeconómica maniféstase nunha distancia física, nunha necesidade, por parte da burguesía, de evitar todo contacto con clases inferiores. Se a novela de Rexina Vega presenta unha familia aferrada á imaxe de burgués "ideal", que trata de gardar as formas e manter as súas fillas afastadas das fillas das pescadoras, malia atoparse a casa familiar aos pés do Berbés, na rúa Real, en Amor de tango de María Xosé Queizán vemos unha rúa do Príncipe de paso restrinxido, 
con horarios de paseo diferenciados segundo o estrato social: "As plebeas debían abandonar a rúa durante o paseo da xente ben. Elas tiñan o paseo das sete da tarde, e, ás oito, todas as pobres para a casa. Había que preservarse de todo contacto" (Queizán 2014: 28).

En Antón e os inocentes, incídese tamén na enorme desigualdade xerada arredor da industria pesqueira, que enriquece a empresarios foráneos (fundamentalmente cataláns) ${ }^{8}$ donos das principais fábricas de salga e conserveiras, dos estaleiros e das fábricas metalúrxicas, e explota un proletariado miseramente recompensado ou, no caso de pequenos patróns, sometido a contratos abusivos de venta do peixe en exclusiva.

O poder que o diñeiro confire a estes industriais permítelles, nalgúns casos, levar a explotación máis alá do terreo económico, con total impunidade: "O industrial [...] [f]ornicou nas obreiras, ciscando fillos bravos nas costas verdescentes, mentres con paciencia seleccionaba pubillas en familias de solvencia prós seus lexítimos vástagos, velando así pola conservación da raza levantina e máis pola saude da empresa familiar" (Méndez Ferrín 1992: 13). Á violación de traballadoras por parte dos "señoritos" alude tamén Queizán en Amor de tango, onde o irmán dun dos personaxes é froito dos abusos cometidos por esa "burguesía industrial terrible, cruel" (Queizán 2014: 124). Dentro do conxunto da sociedade, as mulleres son un dos sectores máis desfavorecidos, condición que parece manterse, segundo a visión de María Reimóndez (2006), ata os nosos días, cando continúan a ser vítimas de violacións e acoso sexual, maltrato, insultos e discriminación.

De entre os barrios máis castigados pola miseria, destacan os periféricos de Bouzas, antiga aldea mariñeira anexionada a Vigo en 1904 (Pereiro Alonso 1981: 56) que acolleu poboación inmigrada e traballadores, e de Teis, onde vive a familia de Petra, unha das personaxes de Ten o seu punto a fresca rosa. Nesta última zona, eminentemente obreira, organizada arredor dos estaleiros de Vulcano, a fábrica Cardama en Ríos e varias conserveiras, a supervivencia é difícil e significa, para moitos, ter que delinquir, polo que á pobreza únense a conflitividade e a droga, especialmente en lugares como Bichita, cuxo nome remite a Wichita, "cidade sen lei, en lembranza do famoso western. Wichita era un conxunto de casas sindicais onde aloxaron ás familias, principalmente de pescadores, do Areal e Guixar, que vivían nas casiñas expropiadas pola Renfe cando construíron a nova vía do tren" (Queizán 2000: 70). Estes barrios son, xunto con outros como Lavadores, Cabral ou Coia, o xerme do movemento sindicalista e da loita obreira, que se radicaliza nos anos 70 , nos derradeiros anos da ditadura franquista, cando se producen importantes folgas obreiras, en Vigo pero tamén en Ferrol, que revolucionan o panorama político en Galicia e que se saldan coa vida de varios obreiros (entre eles, Moncho Reboiras, traballador de Bazán, a quen recordan Queizán e Anxo Angueira).

Como sostén Fran Alonso (2004: 18, 20) en "Vigo, paisaxe urbana", a filmografía recente que escolle a cidade como escenario explota a súa dureza, a súa aparencia

8 Durante o reinado de Carlos IV, época de expansión xeral da economía, a inmigración catalá en Vigo e a súa intervención no sector da pesca foron masivas, e chegaron a coñecer, ata ben entrado o século XX, unha prosperidade notable (Mejide Pardo 1979) grazas, sobre todo, ao incremento na produción da sardiña, debido a tres factores fundamentais: o aumento das capturas polo emprego de novas técnicas extractivas (xávega), unha manipulación máis racional do produto (salga e conserva) e unha nova organización do traballo (sistema de traballo doméstico e sistema de traballo asalariado) que marca o inicio da historia do proletariado burgués (Pereiro Alonso 1979). 
hostil debido a un crecemento súpeto e desproporcionado. Los lunes al sol presenta outro barrio obreiro deprimido, desolado polo paro resultante da reconversión industrial de Vigo e do peche do que fora un dos principais motores da cidade, os estaleiros (neste caso os ficticios Aurora, pero ben podería tratarse de ASCON), malia a oposición, as folgas e as protestas de boa parte dos seus traballadores, que agora intentan en van reincorporarse ao mundo laboral. Negocios case desertos, edificios deteriorados, casas sen subministración de auga nin electricidade... forman un panorama tan desolador como as instalacións dos estaleiros, destinadas a converterse en solo edificable.

Aínda que o capital vai cambiando de mans e de sector, a igualdade non é máis que unha ilusión: "[...] a cidade, configurada en aparencia coma un taboleiro para o xogo colectivo en pé de igualdade, tremía baixo a presión extenuante dos poderosos" (Cid Cabido 1994: 36). Panificadora retrata unha cidade con barrios pobres, con casas de pedra ou cemento e teito de uralita pintadas de cores, cubertas por musgo, con estancias miserables. O edificio da empresa Chup \& Chup, tamén chamada a Perversa, álzase por riba da urbe e dos seus habitantes, dominándoos e non obstante ignorando "a súa existencia de seres menores sumidos na degradación e na laceira imposta polo programa do imperio empresarial" (Cid Cabido 1994: 56). Esa clase poderosa, representada espacialmente polo monstruoso edificio, ameaza a cidade e os seus cidadáns, cuxo abandono simboliza a xigante construción da Panificadora, silenciosa, ruinosa e baleira para sempre do "gran para o pan de comer a xente" (Cid Cabido 1994: 125).

Outro problema social que sacude Galicia e ten repercusións nas representacións de Vigo é a emigración. O porto de Vigo é a gran porta do éxodo masivo de galegos, principalmente cara ao outro lado do océano, cara a esa América que, en palabras de Rexina Vega (2007: 70) "dá homes sen rumbo e deixa a Galicia como un país baldeiro só apto para lúbricos homes gordos e vellos usureiros". Os peiraos do porto convértense en punto de partida dunha nova aventura en busca dun futuro mellor, esperanza que a miúdo se trunca antes de comezar, ao contemplar a dor da familia que fica e a miseria e a incerteza nos rostros de quen marcha:

Porque el, como moitos outros vigueses, preferira ver naquel peirao de embarque dos grandes transatlánticos, polo que desaparecían miles de persoas cada ano, unha esperanza, unha saída épica ante a asfixia e o fastío da provincia, como unha porta ao progreso e ao mundo ancho. Agora que era el mesmo o que camiñaba arrepiado cara ás grandes fauces da balea, agora que estaba alí a carón de tanta xente pobre, analfabeta, sucia [...] comprobaba a dureza daquel destino. [...] Estaban deixando nesta beira a súa sombra, a súa fantasma, perdendo o equilibrio da raíz (Vega 2007: 122-123).

A cidade, polo tanto, é espazo que expulsa, que obriga a buscar fóra o sustento que non pode ofrecer, e o porto, o escenario que evidencia a desgraza, como ben condensan os versos de Anxo Angueira (2006: 49): "aquí na Pedra Laxe / tódolos ollos do éxodo". Os emigrantes participan dun mercado humano, no que outros, propietarios de navieiras, estaleiros e industrias relacionadas, se enriquecen grazas ao tráfico de campesiños que venden os seus escasos recursos para mercar a pasaxe cara aos EE.UU (como Fasito en Cardume), Venezuela (como o pai de Narda en Antón e os inocentes), Cuba, Arxentina... destinos onde poucos lograrán "facer as Américas" 
e outros moitos serán "explotados como bestas, moitas veces polos propios galegos, polos que se enriqueceran e eran peores [...]” (Queizán 2014: 69).

Para quen fica, as condicións, ata entón adversas, empeoran. Narda, filla de emigrado, odia o porto vigués, que garda o recordo da partida, e, por extensión, a ría -esa "sopa noxenta" (Méndez Ferrín 1992: 46)- e incluso o mar -"animal abominable [...], un símbolo nebuloso, letal, da súa disgracia” (Méndez Ferrín 1992: 107)-. Non obstante, o paso do tempo vai tornando familiares e tolerables a estación marítima, os peiraos, as tabernas mariñeiras, o propio mar e, sobre todo, as praias, escenario dos seus encontros amorosos con Berto. Para a protagonista de Adiós María de Xohana Torres, cuxos pais emigran a Lille ao quedar o pai sen traballo tras o peche do tranvía, ${ }^{9}$ Cantador, ata entón acolledor malia e precariedade económica, vaise volvendo cada vez máis opresivo e asfixiante. Maxa, con só quince anos, queda ao cargo da casa, das tarefas domésticas e do seu irmán pequeno, baixo a vixilancia extenuante da súa avoa, quen, a pesar dos sacrificios da moza (que tivo que renunciar á súa educación e máis á súa vida social), non escatima en reproches.

O mar, o porto, as praias... son un espazo nuclear na cidade e como tal permanecen nas obras que a recrean. É, de acordo co dito, un espazo híbrido, capaz de xerar sentimentos contraditorios, que está presente nos textos e filmes tratados, como o estivera xa nos seus precedentes. Desde as cantigas de Martín Códax e Mendiño, Vigo aparece sempre vencellado ao seu mar, en moitas ocasións é incluso eclipsado por el. Cara ao mar ollan as voces femininas das cantigas coa esperanza de ver chegar ao seu amor; a través del foxen moitos do horror da guerra, que ameaza con estenderse por Europa xa no verán de 1936, como testemuña Zweig; é punto de partida e de chegada dos que van ou foron buscar sorte ás Américas.

Para rematar coa visión de Vigo como medio hostil, cómpre aludir novamente a unha situación histórica que transcende o plano da literatura e é recreada na maior parte das obras tratadas: o alzamento militar, a Guerra Civil e a posterior represión. O 20 xullo de 1936 o conflito estala en Vigo. Queizán (2014) e Vega (2007) retratan eses momentos iniciais. Cos primeiros tiroteos e as primeiras mortes, que teñen lugar na Porta del Sol (que non tardaría en cambiar o seu nome polo de Capitan Carreró, protagonista do levantamento en Vigo), a confusión e o medo apodéranse da cidade, e pronto o caos é xeral: peche de teatros, cese de xornais, piquetes, trincheiras, barricadas nas rúas... As consecuencias para os defensores da República non se fan esperar: comezan as detencións, os "paseos", os fusilamentos.

Nesta cidade turbulenta, no período bélico e posbélico, dous son os espazos que máis sobresaen: o cárcere da rúa do Príncipe e a prisión da illa de San Simón. No primeiro deles, o actual MARCO (Museo de Arte Contemporáneo), que albergaba na súa parte dianteira os xulgados e na traseira o presidio, encerran e fusilan ao pai dunha das protagonistas de Amor de tango, tras un intento desesperado e inútil da súa familia por liberalo. Á hostilidade inherente a un espazo de reclusión e morte engádese a derivada do negocio fraudulento levado a cabo por Búa, director do centro, e o médico Bustelo. Ambos os dous, antes de seren xulgados e fusilados polo réxime, vendían aos presos condenados a morte unha liberdade que nunca chegaría,

A Compañía Anónima Tranvías Eléctricos de Vigo estableceu unha extensa rede de tranvías en Vigo que modelou a cidade que coñecemos hoxe (Pereiro Alonso 1981: 63). Activo desde 1914 ata 1968, unía o centro urbano con barrios periféricos como Bouzas, Samil, Pereiró, Lavadores, Cabral ou Teis e con outros municipios como Chapela, Baiona e outros da comarca do Val Miñor. 
como recorda Queizán (2014). É neste mesmo espazo, “o casón poeirento e duro de Príncipe" (Méndez Ferrín 1992: 133) onde, décadas despois, cumpre condena o pai de Berto en Antón e os inocentes.

Urbano, un dos personaxes de Cardume, é apresado en San Simón, lugar emblemático da represión franquista e da memoria histórica (Sánchez-Carretero 2013: 3233), habilitado para facer fronte ao elevado número presos, que o cárcere de Príncipe non podía conter (Sánchez-Carretero 2013: 37). Esta illa, antano familiar e fermosa, visible desde a súa casa, vólvese agora sinistra, “[...] unha terra de ninguén, [...] un espazo estraño e maldito" (Vega 2007: 152). A reclusión neste lugar, en condicións infrahumanas, síntese dobremente: ás catro paredes do antigo lazareto cómpre engadir o mar que o rodea, a tranquila ría que é sentida agora como a maior das ameazas e que o separa aínda máis dunha liberdade que nunca había chegar: nas súas augas afundirase o corpo de Urbano, como o de tantas outras vítimas do réxime.

O Vigo da guerra é lembrado tamén por Anxo Angueira (2007), quen, ademais de facer referencia a estes dous centros penais (e ao barco prisión Upo Mendi, que pretendía ser integrado no sistema concentracionario de San Simón), rescata en Fóra do sagrado outros episodios da Guerra Civil. De entre eles destacan o fusilamento do 27 de agosto en Pereiró dos membros do Comité do Fronte Popular, entre os que se atopaban o alcalde Emilio Martínez Garrido e o alcalde de Lavadores José Antela Conde; ou o do bou Eva, no que nove persoas planeaban fuxir a Francia e no que finalmente se suicidaron tras seren delatados e acantoados nas bodegas por un grupo de falanxistas. Eco deste mesmo episodio parece ser a historia do pai de Daniel, coñecido como Eneas Dafonte, personaxe de Os fillos do mar que morre asasinado por intentar sacar do país, agochados na bodega dun barco, a varios republicanos, que falecen alí mesmo despois de que varios falanxistas inundaran o seu escondedoiro (Feijoo 2013: 304-305).

\section{A outra cara de Vigo: trazos positivos}

Malia que a representación de Vigo como espazo hostil é a dominante no corpus analizado, aparecen nas obras tratadas, incluso nas máis negativas no que a ambientación urbana se refire, descricións e reflexións que a moderan, ao pór de relevo trazos positivos da cidade olívica. Por exemplo, Fran Alonso, que en Cemiterio de elefantes ofrecía unha imaxe devastadora da cidade, en Cidades dedícalle palabras máis amables. Por enriba de todos os seus defectos, sobresaen a necesidade de regresar a ela e o sentimento de pertenza: "Pero eu quéroa porque / é a cidade onde nacín" (Alonso 2013: 13) e porque poder ofrecer espectáculos de "unha beleza inmensa, / e non hai palabra ningunha / capaz de describila" (Alonso 2013: 39).

Case todas estas descricións que contrastan con esoutra cara hostil teñen como obxecto a paisaxe natural, principalmente a ría e os seus arredores, coa Península do Morrazo en fronte e as illas Cíes custodiando a entrada á baía desde o océano. Cadros que subliñan a beleza do entorno poden encontrarse nas novelas de Queizán e nas de Pedro Feijoo, que se recrean incluso na maneira en que a luz, segundo o momento do día do que se trate, incide sobre a superficie das augas, que dominan a paisaxe. Por exemplo, en Ten o seu punto a fresca rosa, a fermosura natural actúa como contrapunto ao acto homicida, pois a narración da morte de María, no monte 
de O Castro, acompáñase dunha longa descrición dunha panorámica da ría ao atardecer, na hora da quietude e do silencio, quietude e silencio dos que participan tanto o medio como a vítima:

O sol xa se perdera polas illas Cíes e o resplandor afogueado que deixara na baía fórase apagando. Poucas escenas poden igualar a fermosura dunha posta de sol na ría de Vigo, contemplada desde a atalaia do monte do Castro. Os barcos abeirados nos diferentes peiraos, o de transatlánticos, o comercial, e os de mar. Os grandes conxeladores que chegaran do Gran Sol ofrecían a súa imaxe forte ante os pequenos pesqueiros, os bous ou as bacas de pesca de baixura. Nos peiraos, as grúas inclinábanse sobre o espello marítimo como garzas industriais e estáticas [...].

[...] O astro vaise inclinando sobre a península do Morrazo, o lado oposto da ría, fronte á cidade, e sobre as illas Cíes, tres escarpadas monatañas que protexen a baía das iras atlánticas. A medida que o sol se achega ao mar para afogarse lentamente nel, vai plantando lume nas augas calmas da ría, irisadas e radiantes coma se a luz xurdira do interior, das profundidades oceánicas, do plancto mariño, dos ollos dos peixes. Era un espectáculo marabilloso que as xentes de Vigo sabían apreciar e non cansaban de contemplar, porque, ademais, nunca era igual. Cada posta de sol tiña os seus matices" (Queizán 2000: 136).

Vigo, "fermoso monstro deitado a pé do Atlántico" en palabras de Feijoo (2013), é, polo tanto, a combinación dun entorno natural privilexiado e unha paisaxe humana desordenada, ${ }^{10}$ na que, incluso para as voces máis críticas co desenvolvemento urbanístico, hai construcións que merecen ser rescatadas da condena. É o caso das obras de Paczevich ou dos irmáns Gómez Román, arquitectos aos que se deben algúns dos edificios máis emblemáticos do centro urbano, e que reivindican Anxo Angueira (2006), Queizán (2000, 2014) ou Pedro Feijoo (2013).

Ao marxe do aspecto externo da cidade, é interesante ver como entre as connotacións dos espazos, naturais e construídos, hai tamén valores positivos, que rebaixan un pouco a súa carga hostil e convérteos en lugares ambiguos. Así, por exemplo, o porto, que como vimos era escenario de desigualdade, de despedidas e de morte, é asemade un lugar de chegada de xente de distintos lugares e distintas culturas, un lugar cosmopolita, de tránsito, de movemento, que da vida á cidade. Deste xeito, como espazo oposto á cerrazón, ao fastío da casa sen pais, percíbeo Maxa en Adiós María: "a min os peiraos gústanme moitísimo, estes peiraos da vila son enormes, pasea e vai e vén a xente algo descontrolada, soben, baixan, falan en voz alta, persoas de toda clase. Polos porches están as vendedoras, os turistas mercan sombreiros de alas grandes que logo poñen na cabeza e se escachan coa risa [...]" (Torres 2000: 134). É un enclave propicio para o soño, para a imaxinación doutros mundos e doutras vidas posibles. O porto e a ría son tamén espazos liberadores para Charo, personaxe de Ten o seu punto a fresca rosa (Queizán 2000), quen, durante un largo encerro nunha clínica psiquiátrica, recorre á imaxe do mar, ao seu recordo, para superar os momentos máis críticos.

Outro lugar ambiguo, presente en varias das obras estudadas, é o cemiterio de Pereiró. Se en principio a función deste espazo e o feito de ser testemuña da dor das

$10 \quad$ A este respecto afirma Pereiro Alonso (1981: 236): "Hablar de belleza en la ciudad de Vigo como obra colectiva es un contrasentido. La belleza está fuera, en el paisaje, en la ría, en los montes que la circundan. Puede afirmarse que desde que fueron demolidad las murallas de la ciudad [...], la belleza quedó oculta bajo sus escombros". 
familias levan a clasificalo como hostil, o certo é que, tal e como é recreado, eríxese como a reivindicación dun pasado que se quixo soterrar xunto cos seus mortos: o da Segunda República. Concretamente, a parte do antigo cemiterio civil, ese espazo "fóra do sagrado" ao que remite o título do poema de Anxo Angueira, en contraposición ao verso de Martín Códax, ${ }^{11}$ é o bastión da II República; garda no seu interior, entre outros, os mortos da infamia (Vega 2007: 11), os inimigos do réxime, os mortos da guerra. Tanto en Cardume como en Antón e os inocentes, varios personaxes chegan a este lugar para tirar caraveis vermellos -algúns ao berro de "¡Viva a República"! (Vega 2007: 11) en tempos nos que ese xesto podía custar a vida-, sobre as tumbas de Ricardo Mella, o socialista Heraclio Botana (fusilado o tráxico 27 de agosto do 37) ou Eugenio Arbones. En ambas as novelas este espazo presenta unha atmosfera pacífica, amable, humana, a pesar dos muros e as portas que o separaban de terreo "sagrado" (e que só serán derrubadas tras a morte de Franco), do desamparo e da ausencia total de ornamentación.

En moitos dos autores tratados nótase unha vontade clara de subliñar o carácter progresista da cidade de Vigo, rescatando a súa próspera vida cultural (especialmente durante a Segunda República); a resistencia dos seus habitantes ao sometemento ao longo da historia; a súa capacidade de mobilización e asociación, que a convirte, segundo Fran Alonso (2004), nunha das cidades máis vivas de toda Europa. Nestes aspectos, a pesar da violencia e demais consecuencias adversas que poden traer consigo, reside a auténtica forza da urbe, a súa face amable, na que deben apoiarse os vigueses para superar ese complexo de autoanulación arrastrado historicamente, así como a percepción negativa do espazo que habitan. Fronte á notoria hostilidade que caracteriza ao Vigo da súa novela, e que se suaviza cun ton máis agradable na poesía, atopamos en "Vigo, paisaxe urbana" unha defensa férrea da cidade, a súa cidade:

Con todo, Vigo é unha cidade aberta, dinámica, autocrítica, solidaria, cunha capacidade de superación e de avance como poucas. [...] un lugar ao tempo fermoso, escuro e brillante, cun entorno privilexiado, con rúas inconfundibles, con lugares atractivos, aínda por remodelar, por revitalizar, de fortísima personalidade, de grandes contrastes, progresista, de vocación cosmopolita (Alonso 2004: 20-21).

Neste sentido cabe interpretar o extenso poema de Anxo Angueira, no que, baixo esa aparente crítica a unha urbe inclemente, escenario de episodios crueis, baixo esa vontade de dicir adeus a un Vigo que xa non ten nada que ofrecer, subxace unha verdadeira oda á cidade olívica. A obra, que realiza un repaso polo legado histórico, literario, musical, xornalístico, arquitectónico, etc. de Vigo, especialmente do século XX, detense nos aspectos que a consagran como a capital cultural, a cidade contra a norma, a cidade combativa, a urbe pagá:

Vigo que rompe nas rompentes / e cómo custa decerlle adeus / ó Vigo de metal / adeus ó 72 e ó 84 e ó 06 / coma illas / para sempre tatuados nos mares / nos océanos do noso corazón / e moito coidadiño / foi medrando e facéndose aceiro / Vigo / Vigo Ferrol na febre forxadora / dos novos almanaques 72 / folga forxa de que si / ó Vigo vigoroso vulcano berro berro / ó brado metalúrxico / alto resumo folga

11 "Eno sagrado, en Vigo", pertencente a unha das súas cantigas. 
é a consigna / antifranquista antipactista / reconversación farrapos folga folga / forxa de Vigo de Ferrol / de Rebooiras Noia Xosé González García Crego obreiros / peritos da nación obreira / de metal / adeus que eu voume / con Diego Lence con / Manolo Camaño deica Príncipe puño Porta do Sol / benigno Vigo / que comemos bragada Bragadelas / que andamos arremangados Canicouva / Vigo perenne eterno maio / primeiro irei madre a Vigo / e logo bañarnos hemos nas ondas / vernellas / das bandeiras neboentas / vermellas do Berbés señor señor / en Vigo nas avenues / dos estaleiros das conserveiras / das confederacións dos sindicatos / das centrais das unións das libres libres (2006: 40-41)

Esa dialéctica constante entre virtudes e defectos, vergoñas e orgullo, denuncia e reivindicación, que está en maior ou menor medida presente en todas as obras analizadas, resólvese nos versos finais do longo poema, que serven tamén de colofón a este traballo: "ollos que riron contigo / unicamente os ollos / que soñaron contigo / Vigo/ liberdade” (Angueira 2006: 56).

\section{Bibliografía:}

Alonso, Fran (2004): "Vigo: paisaxe urbana", en A cidade e a palabra. XXI Encontro de Escritores Galegos, Vascos e Cataláns. Grial Cadernos. Vigo: Editorial Galaxia, pp. 17-23.

- (2007): Cemiterio de elefantes. Vigo: Xerais.

- (2013): Cidades. Vigo: Xerais.

Angueira, Anxo (2007): Fóra do sagrado. Vigo: Xerais.

Branco, Carmen (2006): "Morrer no mar de mulleres desecado. Unha lectura de Adiós María de Xohana Torres", en Xaquín Rodríguez Campos, José Manuel Santos Solla (eds.): Galicia \& Terranova \& Labrador: Comparative Studies on Economic, Political and Socio-cultural Processes: Proceedings of the International Congress, Santiago de Compostela, October 28-31, 2002. Santiago de Compostela: Publicacións Universidade de Santiago de Compostela, pp. 181-192.

Cid Cabido, Xosé (1994): Panificadora. Vigo: Xerais.

Feijoo, Pedro (2013): Os fillos do mar. Vigo: Xerais. E-book.

- (2017): Os fillos do lume. Vigo: Xerais. E-book.

- (2018a): Camiñar o Vigo vello. Un paseo pola historia da cidade. Vigo: Xerais.

- (2018b): Sen piedade. Vigo: Xerais. E-book.

Forcadela, Manuel (s.d.): "Vigo literario", en "Roteiros literarios", en Asociación de Escritores en Lingua Galega http://www.aelg.gal/centro-documentacion/autores-as/manuel-forcadela/paratextos/2443/vigo-literario/q/vigo\%20literario [09/10/2018].

Mejide Pardo, Antonio (1979): “Aspectos de la vida económica en Vigo en el siglo XVIII”, en Álvaro Cunqueiro y José María Álvarez Blázquez (coord.): Vigo en su historia. Vigo: Caja de Ahorros Municipal de Vigo, pp. 280-355.

Méndez Ferrín, Xosé Luis (1992): Antón e os inocentes. Vigo: Editorial Grupo ACSA- Diario 16 de Galicia.

Pereiro Alonso, José Luis (1979): "El urbanismo vigués contemporáneo", en Álvaro Cunqueiro y José María Álvarez Blázquez (coord.): Vigo en su historia. Vigo: Caja de Ahorros Municipal de Vigo, pp. 563-608.

- (1981): Desarrollo y deterioro urbano de la ciudad de Vigo. Santiago de Compostela: Publicacións do COAG. 
Popeanga Chelaru, Eugenia (2015): "De la ciudad hostil a la ciudad sin atributos", en La ciudad hostil: imágenes en la literatura. Madrid: Síntesis, pp. 31-45.

Prada-Trigo, José (2015): "De la ciudad hostil a las hostilidades humanas", en Eugenia Popeanga (coord.): La ciudad hostil: imágenes en la literatura. Madrid: Síntesis, pp. 47-56.

Queizán, María Xosé (2000): Ten o seu punto a fresca rosa. Vigo: Xerais.

- (2014): Amor de tango. Vigo: Xerais.

Reimóndez, María (2006): O club da calceta. Vigo: Xerais.

Sánchez Carretero, Cristina (2013): "Patrimonialización de espacios represivos: en torno a la gestión de los patrimonios incómodos en España”, en Carmen Ortiz García (coord.): Lugares de represión, paisajes de la memoria: aspectos materiales y simbólicos de la cárcel de Carabanchel, pp. 28-41

Torres, Xohana (2000): Adiós María. Vigo: Galaxia.

Vega, Rexina (2007): Cardume. Vigo: Xerais.

\section{Filmografía:}

Herrero, Gerardo (dir.) (2005): Heroína. España: Tornasol Films.

León De Aranoa, Fernando (dir.) (2002): Los lunes al sol. España: Mediapro.

Tapia, Gonzalo (dir.) (2001): Lena. España: Alta Films. 